\title{
ASSESSMENT OF HEALTH CONDITION AS RELATED TO LIFESTYLE AMONG STUDENTS IN THE EXAMINATION PERIOD
}

\author{
ALEKSANDRA JAREMKÓW, IWONA MARKIEWICZ-GÓRKA, and KRYSTYNA PAWLAS
}

\author{
Wroclaw Medical University, Wrocław, Poland \\ Department of Hygiene
}

\begin{abstract}
Objectives: The aim of this paper was to investigate the impact of changes in the students' lifestyle during an examination period on their health condition, as evidenced by changes to the body composition and metabolic rates. Material and Methods: The study involved 268 Wroclaw Medical University students (second- and third-year students). The study was performed 3 times (at the beginning of a semester, in the middle of a semester, and in the examination period) and included a completion of a questionnaire on the current lifestyle, as well as measurements of the body composition, the basal metabolic rate, and the waist and hip circumferences. The measurements were carried out with the use of a body composition analyzer (Tanita MC-780 MA) and a tape measure with a waist-hip ratio calculator. Results: In the examination period, as compared with the rest of the semester, a significant decrease was observed in the metabolic rates, and the body water and muscle mass of the examined students. During that period, there were also more frequent adverse changes in the students' lifestyle. In the studied periods, a correlation was found between changes in the frequency of snacking, consuming sweets and cola drinks, and the alterations of the subjects' body fat mass, i.e., $r=0.161, r=0.135$, and $r=0.143$, respectively. In turn, differences in the frequency of drinking wine, physical activity, sleep length, and time devoted to learning correlated with changes in the participants' body water, i.e., $\mathrm{r}=0.140, \mathrm{r}=0.152$, and $\mathrm{r}=0.133(\mathrm{r}=-0.142, \mathrm{r}=-0.147)$, respectively, and muscle mass, i.e., $\mathrm{r}=0.141$, $\mathrm{r}=0.142$, and $\mathrm{r}=0.126(\mathrm{r}=-0.130, \mathrm{r}=-0.142)$, respectively, and metabolism, i.e., $\mathrm{r}=0.127, \mathrm{r}=0.145$ and $\mathrm{r}=0.135(\mathrm{r}=-0.127, \mathrm{r}=-0.135)$, respectively. Conclusions: The analysis of the body composition and metabolic rates of the students during an examination period indicates that the changes occurring in various elements of their lifestyle (e.g., dietary habits, physical activity) can result in deteriorating their health condition. Int J Occup Med Environ Health. 2020;33(3):339-51
\end{abstract}

Key words:

body composition, feeding behavior, health, lifestyle, metabolism, students

\section{INTRODUCTION}

The majority of papers on young people's lifestyle indicate that their knowledge concerning proper nutrition is not always followed by proper dietary behaviors [1]. As pointed out by Radziminska [2], students of medical universities present better health attitudes than students of other faculties. This results primarily from the specificity of their studies, which include dietary education in the curricula. Moreover, being fit has become fashionable in recent years, making more and more people reach for healthy food and practise sports eagerly. According to European data (Special Eurobarometer 472), the number of physically active people has increased (40\% in the European Union) [3]. Nevertheless, overweight and obesity among young people still constitute a global issue [4].

Funding: this study was supported by the Wroclaw Medical University from the funds granted by the Minister of Science and Higher Education (project No. STM. A100.17.056 entitled "Assessment of health condition as related to lifestyle among students in the examination period," project manager: Aleksandra Jaremków, Ph.D.). Received: October 8, 2019. Accepted: January 31, 2020.

Corresponding author: Aleksandra Jaremków, Wroclaw Medical University, Department of Hygiene, Mikulicza-Radeckiego 7, 50-345 Wrocław, Poland (e-mail: aleksandra.jaremkow@umed.wroc.pl). 
So far, most studies have focused on the generally understood lifestyle of students, without considering the different academic year periods that impact on their health behaviors (the semester of didactic classes and the examination period). These are completely dissimilar periods of academic life, which can shape different health attitudes. An examination period is a time of intensified mental work, frequent stress experience, and sleepless nights. It is, therefore, justified to presume that significant changes in the students' lifestyle, resulting in a deteriorated health condition, can occur in that period.

The research that applied a body composition analyzer to examine student population indicated that an increase in the weight, body mass index (BMI) [5,6], and waist circumference [6] occurred during studies, especially in males. In females, these indices generally remained stable, which could result from a greater care of their appearance. The correlation of some lifestyle factors with students' body composition parameters and metabolic rates has been investigated by several researchers. These studies mostly involved the period of the beginning of studies (the first semester [5,7]). In turn, there are more studies focusing solely on changes in the students' body mass and BMI (without any body composition analysis) [7-10]. The majority of this research aimed to inspect the changes occurring in young people's lives at the time of transition from secondary school to adulthood, and the associated independence in everyday life. There are, however, no studies evaluating the health condition of students in the most important period of the academic year, i.e., the examination period. Although lasting 2 weeks only, this is the time of permanent stress for most students.

The aim of this paper was to investigate the impact of changes in the students' lifestyle during an examination period on their health condition, as evidenced by changes in the body composition and metabolic rates.

\section{MATERIAL AND METHODS}

\section{Study design}

The study involved a group of Wroclaw Medical University students (second- and third-year students), the Faculty of Medicine. The examination, including a questionnaire survey, a body composition measurement, a basal metabolic rate (BMR) indication, and anthropometric measurements, was performed 3 times: at the beginning of a semester, in the middle of a semester, and in the examination period. All the 3 series involved 268 students. The study was approved by the Ethics Committee of the Wroclaw Medical University, Poland (approval No. KB 524/2017; KB 46/2018).

\section{Questionnaire survey}

At the beginning of the winter semester, the students were informed about the course of the research. Those who volunteered to participate and provided their consent were asked to complete a questionnaire on their current lifestyle (i.e., referring to the investigated period). The questionnaire included items concerning the consumption of energetic drinks, other drinks containing caffeine, alcohol, experienced stress, sleeping habits, physical activity, and dietary habits: the type of food, the frequency of consumption, the number of meals per day, and the dietary supplements intake.

\section{Body composition analysis}

A body composition analyzer (Tanita MC-780 MA), utilizing the bioelectrical impedance analysis method, served to measure the students' body composition; the subjects' BMR was also calculated.

Prior to each measurement with the use of the body composition analyzer (the same time of the day), the students were instructed on the way they should prepare for the examination (the measurement was performed at least $3 \mathrm{~h}$ after getting up, $3 \mathrm{~h}$ after a meal, $12 \mathrm{~h}$ after intense physical effort, $12 \mathrm{~h}$ after alcohol intake, after urination; and in women 
- outside pregnancy and menstruation). The measurement was carried out in accordance with the device usage instructions (barefoot, in light clothes, without jewellery).

\section{Anthropometric measurements}

At the beginning of the study, the participants' body height was determined using a stadiometer. Each time, a tape measure with a waist-hip ratio (WHR) calculator served to establish the subjects' waist and hip circumference. All the measurements were taken twice, and then their mean was calculated. Types of obesity were defined on the basis of the WHR index and followed the World Health Organization standards [11]: gynoid obesity: WHR $<0.90$ in men, WHR $<0.85$ in women; and android obesity: WHR $\geq 0.9$ in men, WHR $\geq 0.85$ in women.

\section{Statistical analysis}

Statistical calculations were performed using the Statistica 12.5 software for Windows. The anthropometric and body composition parameters were compared across the studied periods (both for the whole population and by gender). For this purpose, a repeated measures analysis of variance was carried out with the post-hoc Bonferroni test (some tests were applied after the logarithmic transformation of the variables). In turn, a non-parametric test for dependent variables, post-hoc Friedman's analysis of variance, served to compare the changes in the students' lifestyle (quantitative changes) occurring during the semester of didactic classes and in the examination period. In order to demonstrate the dependence between the changes occurring in the students' lifestyle and those in their body composition, Spearman's rank correlation test was performed. The significance level of $p<0.05$ was assumed for all these analyses.

\section{RESULTS}

\section{Study group characteristics}

The characteristics of the study population are presented in Table 1 . The study involved $58.2 \%$ of women and $41.8 \%$ of men, with the mean age of ca. 21 years. Most participants were second-year students. The subjects' body height range was $149.2-178.5 \mathrm{~cm}$ for women, and $158.0-196.0 \mathrm{~cm}$ for men. The students came from both bigger and smaller localities (with a slight predominance of cities $>100000$ inhabitants). The majority rented a room or apartment. More than a half lived in a rather peaceful neighborhood, but the environment was noisy in a still considerable number of cases (almost 40\%).

\section{Changes in anthropometric and body composition parameters}

The students' body composition changed during the semester (Table 2), especially in the examination period (period 3) as compared with the didactic classes period (periods: 1 - the beginning of the semester and 2 - the middle of the semester). At the beginning of the academic year, a normal BMI was observed in $79.8 \%$ of the students, underweight in $8.6 \%$, and overweight or obesity in $11.6 \%$, of whom $10.1 \%$ presented gynoid obesity; in the middle of the semester, the respective values were $77.6 \%, 10.8 \%$, and $11.6 \%(10.1 \%$ gynoid obesity); and in the examination period, they equaled $78.7 \%, 9.3 \%$, and $12.0 \%$ (11.2\% gynoid obesity), respectively. Four months after the beginning of the academic year, the body mass (including BMI) significantly decreased only in women. In the whole studied group, a significant decrease in the BMR and fat-free mass (FFM) indices, as well as in the body water and muscle mass, was observed in the period of most intensified learning as compared with the rest of the semester. In the examination period, an increase in the students' body mass and body fat percentage was also reported but these changes were not statistically significant.

\section{Changes in lifestyle}

The semester of didactic classes and the examination period were associated with changes in the students' lifestyle as well (Table 3). In the post-holiday time, the students spent most of their time on entertainment (using a computer or 
Table 1. Characteristics of the study population of the Wroclaw Medical University students (Faculty of Medicine) examined in the study on the impact of changes in the students' lifestyle during an examination period on their health condition, 2017-2018, Wrocław, Poland

\begin{tabular}{|c|c|}
\hline Variable & $\begin{array}{c}\text { Participants } \\
(\mathrm{N}=268)\end{array}$ \\
\hline \multicolumn{2}{|l|}{ Age [years] (M \pm SD) } \\
\hline beginning of the semester & $20.7 \pm 1.5$ \\
\hline middle of the semester & $20.8 \pm 1.4$ \\
\hline examination period & $21.0 \pm 1.4$ \\
\hline \multicolumn{2}{|l|}{ Height $[\mathrm{cm}](\mathrm{M} \pm \mathrm{SD})$} \\
\hline total & $172.1 \pm 9.1$ \\
\hline males & $180.2 \pm 6.7$ \\
\hline females & $166.5 \pm 5.5$ \\
\hline \multicolumn{2}{|l|}{ Year of study [n (\%)] } \\
\hline second & $209(78)$ \\
\hline third & $59(22)$ \\
\hline \multicolumn{2}{|l|}{ Gender $[\mathrm{n}(\%)]$} \\
\hline female & $156(58.2)$ \\
\hline male & $112(41.8)$ \\
\hline \multicolumn{2}{|l|}{ Place of origin - family house $[\mathrm{n}(\%)]$} \\
\hline village & $57(21.3)$ \\
\hline \multicolumn{2}{|l|}{ city } \\
\hline$<50000$ inhabitants & $60(22.4)$ \\
\hline $50000-100000$ inhabitants & $55(20.5)$ \\
\hline >100 000 inhabitants & $96(35.8)$ \\
\hline \multicolumn{2}{|l|}{ Type of apartment [n (\%)] } \\
\hline dormitory & $44(16.4)$ \\
\hline rented room & $84(31.3)$ \\
\hline rented or own apartment & $90(33.6)$ \\
\hline family house & $50(18.7)$ \\
\hline \multicolumn{2}{|c|}{ Place of residence - present neighborhood [n (\%)] } \\
\hline heavy traffic; noisy & $106(39.5)$ \\
\hline close to recreational areas; peaceful & $145(54.1)$ \\
\hline moderate traffic & $12(4.5)$ \\
\hline other & $5(1.9)$ \\
\hline
\end{tabular}

a smartphone) and did not follow the rules of healthy nutrition; they most often ate fast food products. In the course of the academic year, on the other hand, they devoted more and more time to learning. In the middle of the semester, the students most frequently applied dietary supplements, and the least frequently (men only) consumed cola drinks. 
Table 2. Changes in the anthropometric and body composition parameters in the Wroclaw Medical University (Faculty of Medicine) students $(\mathrm{N}=268)$ examined in the study on the impact of changes in the students' lifestyle during an examination period on their health condition, 2017-2018, Wrockaw, Poland

\begin{tabular}{|c|c|c|c|c|}
\hline \multirow{2}{*}{ Variable } & \multicolumn{3}{|c|}{$\begin{array}{l}\text { Anthropometric and body composition parameters } \\
\qquad(\mathrm{M} \pm \mathrm{SD})\end{array}$} & \multirow{2}{*}{ F } \\
\hline & $\begin{array}{l}\text { beginning of the semester } \\
\text { (period 1) }\end{array}$ & $\begin{array}{l}\text { middle of the semester } \\
\text { (period 2) }\end{array}$ & $\begin{array}{l}\text { examination period } \\
\quad(\text { period } 3)\end{array}$ & \\
\hline \multicolumn{5}{|l|}{ Weight [kg] } \\
\hline total & $65.1 \pm 12.5$ & $65.0 \pm 12.5$ & $64.9 \pm 12.5$ & n.s. \\
\hline males & $75.1 \pm 10.2$ & $75.1 \pm 10.0$ & $75.0 \pm 9.9$ & n.s. \\
\hline females & $58.0 \pm 8.4$ & $57.8 \pm 8.5$ & $57.7 \pm 8.6^{\mathrm{a}}$ & 3.7 \\
\hline \multicolumn{5}{|c|}{ Basal metabolic rate $[\mathrm{kJ}]$} \\
\hline total & $6627.6 \pm 1247.8$ & $6613.3 \pm 1248.3$ & $6591.1 \pm 1250.0^{\mathrm{a}, \mathrm{b}}$ & 6.8 \\
\hline males & $7866.7 \pm 872.3$ & $7850.3 \pm 873.6$ & $7837.0 \pm 854.8$ & n.s. \\
\hline females & $5738.0 \pm 481.0$ & $5725.3 \pm 488.0$ & $5696.7 \pm 491.4^{\mathrm{a}, \mathrm{b}}$ & 10.8 \\
\hline \multicolumn{5}{|l|}{ Fat mass $[\mathrm{kg}]$} \\
\hline total & $13.0 \pm 5.3$ & $13.0 \pm 5.1$ & $13.1 \pm 5.2$ & n.s. \\
\hline males & $12.1 \pm 4.9$ & $12.1 \pm 4.7$ & $12.2 \pm 4.6$ & n.s. \\
\hline females & $13.7 \pm 5.5$ & $13.6 \pm 5.4$ & $13.7 \pm 5.5$ & n.s. \\
\hline \multicolumn{5}{|l|}{ Fat-free mass [kg] } \\
\hline total & $52.1 \pm 10.7$ & $52.0 \pm 10.7$ & $51.8 \pm 10.8^{\mathrm{a}, \mathrm{b}}$ & 5.6 \\
\hline males & $63.1 \pm 6.9$ & $62.9 \pm 6.9$ & $62.9 \pm 6.8$ & n.s. \\
\hline females & $44.2 \pm 3.9$ & $44.2 \pm 4.0$ & $43.9 \pm 4.0^{\mathrm{a}, \mathrm{b}}$ & 8.1 \\
\hline \multicolumn{5}{|l|}{ Total body water [kg] } \\
\hline total & $37.6 \pm 7.7$ & $37.6 \pm 7.7$ & $37.4 \pm 7.7^{\mathrm{a}, \mathrm{b}}$ & 6.0 \\
\hline males & $45.6 \pm 4.7$ & $45.5 \pm 4.7$ & $45.4 \pm 4.6$ & n.s. \\
\hline females & $31.9 \pm 2.8$ & $31.9 \pm 2.8$ & $31.7 \pm 2.9^{9^{a, b}}$ & 8.9 \\
\hline \multicolumn{5}{|c|}{ Predicted muscle mass $[\mathrm{kg}]$} \\
\hline total & $49.5 \pm 10.2$ & $49.4 \pm 10.2$ & $49.2 \pm 10.3^{\mathrm{a}, \mathrm{b}}$ & 7.4 \\
\hline males & $59.9 \pm 6.6$ & $59.8 \pm 6.6$ & $59.7 \pm 6.5$ & n.s. \\
\hline females & $42.0 \pm 3.7$ & $41.9 \pm 3.8$ & $41.7 \pm 3.8^{\mathrm{a}, \mathrm{b}}$ & 8.8 \\
\hline \multicolumn{5}{|c|}{ Body mass index $\left[\mathrm{kg} / \mathrm{m}^{2}\right]$} \\
\hline total & $21.8 \pm 2.9$ & $21.8 \pm 2.9$ & $21.7 \pm 2.9$ & n.s. \\
\hline males & $23.1 \pm 2.5$ & $23.1 \pm 2.4$ & $23.0 \pm 2.4$ & n.s. \\
\hline females & $20.9 \pm 2.9$ & $20.9 \pm 2.9$ & $20.8 \pm 2.9^{\mathrm{a}}$ & 3.4 \\
\hline
\end{tabular}

n.s. - statisticaly non-significant.

${ }^{a}$ Versus period 1 ( $\left.\mathrm{p}<0.05\right) ;{ }^{\mathrm{b}}$ vs. period $2(\mathrm{p}<0.05)$.

In that period, they also slept the least. In the examination period, as compared with the didactic classes period, the participants significantly more often consumed sweets and drank coffee, and less frequently reached for alcohol. They experienced considerably more stress and devoted less time to physical exercise (women). 
Table 3. Lifestyle changes in the Wroclaw Medical University (Faculty of Medicine) students ( $N=268)$ examined in the study on the impact of changes in the students' lifestyle during an examination period on their health condition, 2017-2018, Wrockaw, Poland

\begin{tabular}{|c|c|c|c|c|}
\hline \multirow{2}{*}{ Variable } & \multicolumn{3}{|c|}{$\begin{array}{l}\text { Students' lifestyle parameters } \\
\qquad(\mathrm{M} \pm \mathrm{SD})\end{array}$} & \multirow{2}{*}{$\mathrm{Chi}^{2 *}$} \\
\hline & $\begin{array}{l}\text { beginning of the semester } \\
\text { (period 1) }\end{array}$ & $\begin{array}{l}\text { middle of the semester } \\
\text { (period 2) }\end{array}$ & $\begin{array}{l}\text { examination period } \\
\text { (period 3) }\end{array}$ & \\
\hline \multicolumn{5}{|l|}{ Consuming frequency } \\
\hline \multicolumn{5}{|l|}{ coffee [times/day] } \\
\hline total & $1.0 \pm 1.0$ & $1.0 \pm 1.0$ & $1.3 \pm 1.3^{\mathrm{a}, \mathrm{b}}$ & 20.6 \\
\hline males & $0.9 \pm 1.1$ & $0.9 \pm 1.0$ & $1.1 \pm 1.4$ & 4.9 \\
\hline females & $1.1 \pm 1.0$ & $1.1 \pm 1.0$ & $1.4 \pm 1.3^{\mathrm{a}, \mathrm{b}}$ & 16.3 \\
\hline \multicolumn{5}{|l|}{ cola [times/week] } \\
\hline total & $1.1 \pm 3.0$ & $0.8 \pm 1.9$ & $0.9 \pm 2.2$ & 6.1 \\
\hline males & $1.3 \pm 2.5$ & $0.8 \pm 1.3^{\mathrm{a}}$ & $1.2 \pm 2.8$ & 11.8 \\
\hline females & $0.9 \pm 3.3$ & $0.7 \pm 2.2$ & $0.7 \pm 1.6$ & 0.1 \\
\hline \multicolumn{5}{|l|}{ wine [times/week] } \\
\hline total & $0.5 \pm 0.9$ & $0.4 \pm 0.6$ & $0.3 \pm 0.5^{\mathrm{a}}$ & 25.3 \\
\hline males & $0.4 \pm 0.8$ & $0.3 \pm 0.5$ & $0.2 \pm 0.4$ & 7.8 \\
\hline females & $0.6 \pm 1.0$ & $0.5 \pm 0.6$ & $0.3 \pm 0.5^{\mathrm{a}, \mathrm{b}}$ & 19.9 \\
\hline \multicolumn{5}{|l|}{ snacking [times/week] } \\
\hline total & $2.8 \pm 2.8$ & $2.7 \pm 2.7$ & $3.1 \pm 2.9$ & 5.6 \\
\hline males & $2.9 \pm 2.9$ & $2.6 \pm 2.7$ & $2.8 \pm 2.8$ & 2.5 \\
\hline females & $2.7 \pm 2.8$ & $2.8 \pm 2.8$ & $3.3 \pm 2.9$ & 6.1 \\
\hline \multicolumn{5}{|c|}{ meat products [times/day] } \\
\hline total & $1.1 \pm 0.9$ & $1.1 \pm 0.9$ & $1.0 \pm 0.9$ & 8.1 \\
\hline males & $1.4 \pm 0.9$ & $1.4 \pm 1.0$ & $1.3 \pm 1.0$ & 2.4 \\
\hline females & $0.9 \pm 0.8$ & $0.9 \pm 0.8$ & $0.8 \pm 0.7$ & 6.0 \\
\hline \multicolumn{5}{|c|}{ fast food [times/month] } \\
\hline total & $3.8 \pm 6.3$ & $3.1 \pm 4.2^{\mathrm{a}}$ & $3.3 \pm 4.8^{\mathrm{a}}$ & 18.8 \\
\hline males & $5.2 \pm 7.2$ & $4.2 \pm 5.4$ & $4.3 \pm 5.5$ & 8.5 \\
\hline females & $2.9 \pm 5.5$ & $2.3 \pm 2.9$ & $2.6 \pm 4.1^{\mathrm{a}}$ & 10.6 \\
\hline \multicolumn{5}{|l|}{ sweets [times/week] } \\
\hline total & $4.1 \pm 3.9$ & $3.9 \pm 4.0$ & $4.6 \pm 4.7^{\mathrm{b}}$ & 9.5 \\
\hline males & $3.7 \pm 3.5$ & $3.5 \pm 4.0$ & $3.8 \pm 4.2$ & 2.0 \\
\hline females & $4.3 \pm 4.2$ & $4.2 \pm 4.1$ & $5.3 \pm 5.0$ & 8.8 \\
\hline \multicolumn{5}{|c|}{ dietary supplements [times/day] } \\
\hline total & $0.5 \pm 0.5$ & $0.6 \pm 0.6^{\mathrm{a}}$ & $0.6 \pm 0.5$ & 19.5 \\
\hline males & $0.5 \pm 0.5$ & $0.6 \pm 0.6$ & $0.5 \pm 0.6$ & 2.9 \\
\hline females & $0.5 \pm 0.5$ & $0.6 \pm 0.5^{\mathrm{a}}$ & $0.6 \pm 0.5$ & 18.5 \\
\hline
\end{tabular}


Table 3. Lifestyle changes in the Wroclaw Medical University (Faculty of Medicine) students ( $\mathrm{N}=268$ ) examined in the study on the impact of changes in the students' lifestyle during an examination period on their health condition, 2017-2018, Wrocław, Poland - cont.

\begin{tabular}{|c|c|c|c|c|}
\hline \multirow{2}{*}{ Variable } & \multicolumn{3}{|c|}{$\begin{array}{l}\text { Students' lifestyle parameters } \\
\qquad(\mathrm{M} \pm \mathrm{SD})\end{array}$} & \multirow{2}{*}{$\mathrm{Chi}^{2 *}$} \\
\hline & $\begin{array}{l}\text { beginning of the semester } \\
\text { (period 1) }\end{array}$ & $\begin{array}{l}\text { middle of the semester } \\
\text { (period 2) }\end{array}$ & $\begin{array}{l}\text { examination period } \\
\quad(\text { period } 3)\end{array}$ & \\
\hline \multicolumn{5}{|c|}{ Physical exercises [times/week] } \\
\hline total & $2.1 \pm 1.8$ & $2.2 \pm 1.9$ & $2.0 \pm 2.0$ & 6.8 \\
\hline males & $2.2 \pm 1.9$ & $2.5 \pm 2.0$ & $2.3 \pm 2.2$ & 2.4 \\
\hline females & $1.9 \pm 1.7$ & $2.0 \pm 1.9$ & $1.7 \pm 1.9^{\mathrm{a}}$ & 10.9 \\
\hline \multicolumn{5}{|c|}{ Feeling stressed [times/week] } \\
\hline total & $2.7 \pm 2.6$ & $2.9 \pm 2.5$ & $3.2 \pm 2.7^{\mathrm{a}}$ & 10.9 \\
\hline males & $2.7 \pm 2.7$ & $2.7 \pm 2.5$ & $2.8 \pm 2.7$ & 1.8 \\
\hline females & $2.8 \pm 2.5$ & $3.0 \pm 2.4$ & $3.5 \pm 2.7^{\mathrm{a}}$ & 14.3 \\
\hline \multicolumn{5}{|l|}{ Sleep length [h/day] } \\
\hline total & $6.8 \pm 1.0$ & $6.5 \pm 1.0^{\mathrm{a}}$ & $6.8 \pm 1.3^{\mathrm{b}}$ & 16.6 \\
\hline males & $6.9 \pm 1.0$ & $6.7 \pm 1.1$ & $6.9 \pm 1.4$ & 3.9 \\
\hline females & $6.8 \pm 1.0$ & $6.4 \pm 1.0^{\mathrm{a}}$ & $6.7 \pm 1.3^{\mathrm{b}}$ & 14.0 \\
\hline \multicolumn{5}{|l|}{ Learning time [h/day] } \\
\hline total & $3.0 \pm 1.8$ & $3.9 \pm 1.8^{\mathrm{a}}$ & $6.3 \pm 2.9^{\mathrm{a}, \mathrm{b}}$ & 256.4 \\
\hline males & $2.9 \pm 1.9$ & $3.5 \pm 1.8^{\mathrm{a}}$ & $5.8 \pm 3.2^{\mathrm{a}, \mathrm{b}}$ & 77.7 \\
\hline females & $3.1 \pm 1.7$ & $4.1 \pm 1.8^{\mathrm{a}}$ & $6.7 \pm 2.7^{\mathrm{a}, \mathrm{b}}$ & 182.0 \\
\hline \multicolumn{5}{|c|}{ Using a smartphone [h/day] } \\
\hline total & $2.0 \pm 1.6$ & $1.7 \pm 1.4^{\mathrm{a}}$ & $1.6 \pm 1.2^{\mathrm{a}}$ & 28.0 \\
\hline males & $1.6 \pm 1.3$ & $1.5 \pm 1.2$ & $1.4 \pm 1.0$ & 3.8 \\
\hline females & $2.3 \pm 1.7$ & $1.9 \pm 1.4^{\mathrm{a}}$ & $1.7 \pm 1.4^{\mathrm{a}}$ & 27.8 \\
\hline \multicolumn{5}{|l|}{ Using a computer [h/day] } \\
\hline total & $1.9 \pm 1.4$ & $1.5 \pm 1.3^{\mathrm{a}}$ & $1.5 \pm 1.4^{\mathrm{a}}$ & 22.9 \\
\hline males & $2.1 \pm 1.4$ & $1.9 \pm 1.4$ & $1.9 \pm 1.6$ & 3.6 \\
\hline females & $1.7 \pm 1.3$ & $1.3 \pm 1.1^{\mathrm{a}}$ & $1.2 \pm 1.2^{\mathrm{a}}$ & 23.7 \\
\hline
\end{tabular}

${ }^{a}$ Versus period $1(\mathrm{p}<0.05) ;{ }^{\mathrm{b}}$ vs. period $2(\mathrm{p}<0.05)$.

* ANOVA.

The respondents were also asked about the frequency of consuming fruit and vegetables, cereal products, dairy products, meat, fish, energetic drinks, other products containing caffeine, the amount of water drunk, the number of meals per day, the time interval between meals, and the frequency of snacking and naps during the day. However, no significant changes were observed for these lifestyle elements which would occur over time.

\section{Correlations between changes in lifestyle and in body composition}

Associations were demonstrated between the changes, among others, in dietary habits and the modification of 
Table 4. Significant correlations between changes in the body composition and the students' (Wroclaw Medical University, Faculty of Medicine) $(\mathrm{N}=268)$ lifestyle in the study on the impact of changes in the students' lifestyle during an examination period on their health condition, 2017-2018, Wrocław, Poland

\begin{tabular}{lcccc}
\hline \multirow{2}{*}{ Frequency changes } & \multicolumn{4}{c}{ Spearman's correlation $(\mathrm{r})$} \\
\cline { 2 - 5 } & water mass & muscle mass & fat mass & basal metabolic rate \\
\hline Snacking & - & - & $0.161^{\mathrm{a}}$ & - \\
Meat consumption & - & - & - & $0.123^{\mathrm{a}}$ \\
Sweet consumption & - & - & $0.135^{\mathrm{a}}$ & - \\
Pepsi/cola consumption & - & - & $0.143^{\mathrm{a}}$ & - \\
Wine consumption & $0.140^{\mathrm{a}}$ & $0.141^{\mathrm{a}}$ & - & $0.127^{\mathrm{a}}$ \\
Physical exercises & $0.152^{\mathrm{a}}$ & $0.142^{\mathrm{a}}$ & - & $0.145^{\mathrm{a}}$ \\
Sleep length & $0.133^{\mathrm{b}}$ & $0.126^{\mathrm{b}}$ & - & $0.135^{\mathrm{b}}$ \\
Hours of learning & & & & \\
$\quad$ period 1 vs. 3 & -0.142 & -0.130 & - & -0.127 \\
period 2 vs. 3 & -0.147 & -0.142 & - & -0.135 \\
\hline
\end{tabular}

Period 1 - beginning of the semester; period 2 - middle of the semester; period 3 - examination period.

${ }^{\text {a }}$ Period 1 vs. period $3(\mathrm{p}<0.05)$; ${ }^{\text {b }}$ period 2 vs. period $3(\mathrm{p}<0.05)$.

selected body composition parameters that occurred between the examination period and the remaining part of the semester (Table 4). The differences in the frequency of snacking, consuming sweets and cola drinks were positively correlated with the alterations of the subjects' body fat mass. In turn, the reported decrease in the frequency of drinking wine, physical activity, and sleep length, as well as the increase in the time devoted to learning correlated with the lowering of the students' body water and muscle mass and the BMR index. A positive correlation was also noted between the frequency of eating meat and BMR changes.

\section{DISCUSSION}

The obtained results indicate that the percentage of underweight subjects grew in the examination period, leading to a slight decrease in the mean body mass of the examined students. A significant decrease in the mean body mass in the examination period was reported only among women $(0.3 \mathrm{~kg})$. As a comparison, other research [5-7] revealed that the time of the first semester resulted in a rather significant increase in body mass: of $1-1.5 \mathrm{~kg}$. In the major- ity of cases, however, these results referred to first-year students, who were beginning their studies and were still learning the independence necessary in adult life. In turn, the presented study investigated students of the medical faculty, well informed about the consequences of improper nutrition and lifestyle, owing to the specificity of their studies. Moreover, these were second- and third-year students, already adapted to student life; thus, in these cases, the body mass changes were smaller.

The slight decrease in the students' body mass in the examination period did not, however, result from the loss of adipose tissue, but of body water and muscle mass. This was accompanied by a significant decline in the BMR index. The obtained results may suggest a deterioration of the participants' health condition in the time between the beginning of the semester and the examination period. It should be emphasized that a strong link exists between muscle mass and BMR. Muscles constitute a specific energy-consuming engine. Therefore, a rise in muscle mass results in an increased metabolic rate. Then, the human body is able to burn more calories, which leads to the loss of un- 
necessary adipose tissue [12]. In the case of the examined students, the period of intensified learning contributed to a rather unfavorable direction of body composition changes. A lowered metabolism among students during the first semester was also reported by American researchers [7]. The students' lifestyle changed in the semester of didactic classes and in the examination period. Fast food products were the most popular at the beginning of the semester. In the middle of the semester and in the examination period, i.e., in the time of intensified stress, when there is generally less time to prepare full-value meals, fast food products turned out considerably less frequently consumed. This may result from the fact that medicine students are well informed on healthy nutrition and know that in periods of intensified mental work, there is a higher demand for valuable nutrients than for the high-calorie foods which are low in vitamins and minerals [1]. However, no increase in fruit/vegetables consumption was observed in that period, with the exception of dietary supplements.

In the middle of the semester, the participants drank cola drinks the least frequently (men) and slept the shortest. It could seem that sleep length should increase with a lower intake of drinks containing caffeine [13] (coffee consumption without changes). However, with enhanced stress and more university duties, sleep time could be reduced. According to the research conducted among Warsaw students, more than a half of them maintained that their problems with sleeplessness had resulted from classes lasting till late evening [14]. In the examination period, the students spent most of their time learning, devoting very little time to entertainment. This is completely understandable when one considers the need to acquire the whole semester knowledge in order to pass the examinations. Deliens et al. [5] reported that Belgian students spent more time in front of the computer (for entertainment, playing games) than their Polish peers. However, unlike this study, that analysis of the students' lifestyle did not involve the examination period but the time of didactic classes.
Among Polish students, intensified mental work was accompanied by a significantly more frequent consumption of coffee and sweets than in the period of didactic classes. Coffee is a well-known stimulating and refreshing drink, owing to its caffeine content [15]. It can, therefore, be assumed that its increased intake resulted from the willingness to reduce fatigue and improve concentration, necessary during intensive learning. This remains in line with other articles [16,17] that analyzed students' consumption of coffee or other drinks containing caffeine. In turn, the more frequent reaching for sweets in the examination period could have been caused by the fact that carbohydrates are needed to nourish the brain and make it function better during intensified mental work. However, an excess sugar intake is not recommended either, as it interferes with the formation of new neurons and, thus, slows down the processes of memorizing information [18]. Also, the higher sweets intake could have resulted from stress, which was experienced more often in the examination period than in the rest of the semester. Research by Midoun et al. revealed that eating sweets was among the most frequent students' reactions to stress [19].

It turned out that the students least often reached for alcohol in the period of most intensified mental work. Similar results were obtained, among others, by Zunhammer et al. [20], who reported that German students less often drank alcohol in the examination period as compared with the rest of the semester.

In men studying medicine, the examination period did not cause changes in the frequency of practising sport, as opposed to women. Female students significantly less frequently performed physical exercise in the examination period than in the time of didactic classes. Among students, a negative correlation is generally observed between the level of stress and the frequency of performing physical exercise [21,22].

In order to explain the impact of lifestyle changes in the investigated students on their health condition, the chan- 
ges were correlated with the alterations in the body composition and metabolic rates that occurred between the semester of didactic classes and the examination period. More frequent snacking, consuming sweets and cola drinks were associated with an increase in the subjects' body fat mass. This proves that the unhealthy dietary choices made by the students in the examination period led to improper changes in their body composition (body fat mass increased despite the drop in body mass). Excessive consumption of various sugar-rich products causes the accumulation of fat in the body. The amount of energy supplied this way significantly exceeds the actual caloric needs [23].

The decrease in wine consumption reported in the examination period correlated positively with the drop in the participants' body water and muscle mass, as well as their BMR. The influence of wine on the human body is well documented in literature. When consumed in moderate quantities, wine, as one of few drinks, presents many health-related properties, such as speeding up metabolism [24]. In the presented study, the authors observed a decrease in wine consumption among the students, which could have lowered their metabolic rate to some degree, although this association seems rather accidental, possibly resulting from another dependent factor. The remaining results indicate that the decrease in BMR was also caused, among others, by the lower frequency of physical exercise and the increased amount of time devoted to learning. Research has proven [25] that sedentary lifestyle results in lowering the metabolic rate. The lowered metabolism was accompanied by a decrease in the body water and muscle mass. Sedentary lifestyle usually contributes to the loss of muscle mass and the weakening of muscle function [26]. Muscles are predominantly built up of water (ca. 75\%); therefore, a drop in the muscle mass is associated with a decrease in body water mass.

The changes in the students' body composition were bound with a modification in their sleep length. Litera- ture data on this issue are scarce. A negative correlation between sleep length (during weekends) and an increase in the body fat content was reported by Deliens et al. [5] only, among Belgian students. In this study, increased sleep length was associated with a rise in the amount of time devoted to learning. Although the authors did not verify the examination outcomes of the investigated students, the available data allowed them to conclude that the examination achievements were not affected by sleep length but by going to sleep and getting up early, and, interestingly, by napping during the day [27].

The available literature sources point at a considerable impact of sleep length on metabolism, which is supported by the findings presented in this article (the correlation between $\Delta$ of sleep length and $\Delta \mathrm{BMR}$ ). Both too long and too short sleep disrupts proper metabolism, most often leading to its decrease [28].

In the examination period, the students ate meat slightly less often, which also had a significant impact on lowering their metabolic rate. The digestion and assimilation of protein products demand a somewhat higher amount of energy than in the case, e.g., of carbohydrates. Therefore, consuming meat increases metabolic processes and energy expenditure [29]. However, excessive consumption of meat, containing saturated fatty acids and exerting a ketogenic effect, can adversely influence the human body. Research conducted among Turkish students revealed that too frequent consumption of red meat contributed to metabolic disorders, resulting in an increased BMI [30]. As opposed to these literature data, the frequency of meat consumption by the Polish students, as presented in this study, was moderate (ca. 1/day), and only few participants presented an increased BMI.

\section{CONCLUSIONS}

The results of the presented study prove that significant changes in the students' lifestyle, body composition, and metabolism occur during the semester, and especially in 
the examination period. Although a decrease in the subjects' body mass was observed, this did not result from a reduction in the body fat mass, but in the body water and muscle mass, accompanied by a drop in the BMR index. In the examination period, students led a rather less healthy lifestyle than in the period of didactic classes, which could have resulted in the deterioration of their health condition. This is evidenced by the obtained associations between the lifestyle changes in the investigated students and the modifications in the selected parameters of their body composition that occurred between the examination period and the rest of the semester. However, the strength of these associations is not among the highest $(0.1<\mathrm{r}<0.2)$, probably suggesting that, besides changes in the students' health behaviors, their health condition was also significantly influenced by other factors, not analyzed in the presented study. These should be included in further research, possibly leading to stronger associations. However, the presented study proves that unfavorable changes in the students' lifestyle contribute to lowering their health condition even in such a short time as the examination period.

\section{REFERENCES}

1. Kalemba-Drożdż M. [Nutritional Deficiencies among Young Students]. In: Seń M, Dębska G, editors. Zagrożenia zdrowotne wśród dzieci i młodzieży. Kraków: Oficyna Wydawnicza AFM; 2011. p. 25-33. Polish.

2. Radziminska A, Weber-Rajek M, Lulinska-Kuklik E, Kazmierczak U, Moska W. Academic youth's health behavior. Phys Educ Stud. 2016;20(6):55-62, https://doi.org/10.15561/ 20755279.2016.0607.

3. TNS Opinion \& Social at the request of the European Commission, Directorate-General for Education, Youth, Sport and Culture. Special Eurobarometer 472: Sport and physical activity [Internet]. European Union: European Commission; 2018 [cited 2019 Oct 5]. Available from: https:/ec.europa.eu/ commfrontoffice/publicopinion/index.cfm/Survey/getSurveyDetail/search/472/surveyKy/2164.
4. Ng M, Fleming T, Robinson M, Thomson B, Graetz N, Margono C, et al. Global, regional, and national prevalence of overweight and obesity in children and adults during 19802013: a systematic analysis for the Global Burden of Disease Study 2013. Lancet. 2014;384(9945):766-81, https://doi.org/ 10.1016/S0140-6736(14)60460-8.

5. Deliens T, Clarys P, Van Hecke L, De Bourdeaudhuij I, Deforche B. Changes in weight and body composition during the first semester at university. A prospective explanatory study. Appetite. 2013;65:111-6, https://doi.org/10.1016/j.appet.2013.01.024.

6. Deliens T, Deforche B, De Bourdeaudhuij I, Clarys P. Changes in weight, body composition and physical fitness after 1.5 years at university. Eur J Clin Nutr. 2015;69:1318-22, https://doi.org/10.1038/ejcn.2015.79.

7. Hajhosseini L, Holmes T, Mohamadi P, Goudarzi V, McProud L, Hollenbeck CB. Changes in body weight, body composition and resting metabolic rate (RMR) in first-year university freshmen students. J Am Coll Nutr. 2006;25(2):123-7, https://doi. org/10.1080/07315724.2006.10719522.

8. Economos CD, Hildebrandt ML, Hyatt RR. College freshman stress and weight change: differences by gender. Am J Health Behav. 2008;32(1):16-25, https://doi.org/10.5555/ ajhb.2008.32.1.16.

9. Greene GW, Schembre SM, White AA, Hoerr SL, Lohse B, Shoff S, et al. Identifying clusters of college students at elevated health risk based on eating and exercise behaviors and psychosocial determinants of body weight. J Am Diet Assoc. 2011;111(3):394-400.

10. Wengreen HJ, Moncur C. Change in diet, physical activity, and body weight among young-adults during the transition from high school to college. Nutr J. 2009;8(32):1-7, https:// doi.org/10.1186/1475-2891-8-32.

11. World Health Organization. Waist Circumference and Waist-Hip Ratio. Report of a WHO Expert Consultation [Internet]. Geneva: WHO Press; 2008 [cited 2019 Oct 5]. Available from: https://apps.who.int/iris/bitstream/handle/10665/ 44583/9789241501491_eng.pdf?ua=1. 
12. Müller MJ, Bosy-Westphal A, Later W, Haas V, Heller M. Functional body composition: insights into the regulation of energy metabolism and some clinical applications. Eur J Clin Nutr. 2009;63(9):1045-56, https://doi.org/10.1038/ejcn.2009.55.

13. Gabrish DL. Caffeine Use, Hours of Sleep, and Academic Performance of Undergraduate College Students [master thesis]. Kent: Kent State University College of Education, Health, and Human Services; 2017.

14. Błońska BK, Gotlib J. [Prevalence of sleep disorders among students]. Prz Med Uniw Rzesz Inst Leków. 2012;4:485-97. Polish.

15. Panza F, Solfrizzi V, Barulli MR, Bonfiglio C, Guerra V, Osella A, et al. Coffee, tea, and caffeine consumption and prevention of late-life cognitive decline and dementia: a systematic review. J Nutr Health Aging. 2015;19:313-28, https:/ doi.org/10.1007/s12603-014-0563-8.

16. Franke AG, Christmann M, Bonertz C, Fellgiebel A, Huss M, Lieb K. Use of coffee, caffeinated drinks and caffeine tablets for cognitive enhancement in pupils and students in Germany. Pharmacopsychiatry. 2011;44(7):331-8, https://doi.org/10.1055/s-0031-1286347.

17. Brand R, Koch H. Using Caffeine Pills for Performance Enhancement. An Experimental Study on University Students' Willingness and Their Intention to Try Neuroenhancements. Front Psychol. 2016;7:1-11, https://doi.org/10.3389/ fpsyg.2016.00101.

18. Edwards S. Sugar and the Brain [Internet]. Boston: The Harvard Mahoney Neuroscience Institute; 2016 [cited 2019 Oct 5]. On The Brain Newsletter. Available from: https:// neuro.hms.harvard.edu/harvard-mahoney-neuroscienceinstitute/brain-newsletter/and-brain-series/sugar-and-brain.

19. Midoun E, Salem Y, Akelah D, Abed H, Darwish R, Kerdjani M, et al. Consumption of Sweets and Caffeine under Stress; A Cross-sectional Study among Dental Students in Riyadh, Saudi Arabia. Donn J Dent Oral Hyg. 2018;4(2):023-30.

20. Zunhammer M, Eichhammer P, Busch V. Sleep quality during exam Stress: the role of alcohol, caffeine and nico- tine. PLoS One. 2014;9(10):e109490, https://doi.org/10.1371/ journal.pone.0109490.

21. Nguyen-Michel ST, Unger JB, Hamilton J, Spruijt-Metz D. Associations between physical activity and perceived stress/ hassles in college students. Stress Health. 2006;22:179-88, https://doi.org/10.1002/smi.1094.

22. Cruz SY, Fabián C, Pagán, Ríos JL, González AM, Betancourt J, et al. Physical activity and its associations with sociodemographic characteristics, dietary patterns, and perceived academic stress in students attending college in Puerto Rico. P R Health Sci J. 2013;32(1):44-50.

23. Atkins RC. The Atkins advantage. In: Atkins for life: The complete controlled carb program for permanent weight loss and good health. 1st Martin's Griffin Ed. New York: St. Martin's Griffin; 2004. p. 3-15.

24. Snopek L, Mlcek J, Sochorova L, Baron M, Hlavacova I, Jurikova T, et al. Contribution of Red Wine Consumption to Human Health Protection. Molecules. 2018;23(7):1684, https://doi.org/10.3390/molecules23071684.

25. Mansoubi M, Pearson N, Clemes SA, Biddle SJH, Bodicoat DH, Tolfrey K, et al. Energy expenditure during common sitting and standing tasks: examining the 1.5 MET definition of sedentary behavior. BMC Public Health. 2015;15:516, https://doi.org/10.1186/s12889-015-1851-x.

26. Vella CA, Michos ED, Sears DD, Cushman M, Van Hollebeke RB, Wiest MM, et al. Associations of Sedentary Behavior and Abdominal Muscle Density: The Multi-Ethnic Study of Atherosclerosis. J Phys Act Health. 2018;15(11):827-33, https://doi.org/10.1123/jpah.2018-0028.

27. Eliasson AH, Lettieri CJ, Eliasson AH. Early to bed, early to rise! Sleep habits and academic performance in college students. Sleep Breath. 2010;14(1):71-5, https://doi. org/10.1007/s11325-009-0282-2.

28. Sharma S, Kavuru M. Sleep and metabolism: an overview. Int J Endocrinol. 2010;270832, https://doi.org/10.1155/2010/ 270832.

29. Ciborowska H. [Podstawy żywienia człowieka z elementami biochemii]. In: Ciborowska H, Rudnicka A. [Dietetyka. 
Żywienie zdrowego i chorego człowieka]. 4th ed. Warsaw: PZWL Wydawnictwo Lekarskie; 2018. p. 13-219. Polish.

30. Gunes FE, Bekiroglu N, Imeryuz N, Agirbasli M. Relation between eating habits and a high body mass index among freshman students: a cross-sectional study. J Am Coll Nutr. 2012;31(3):167-74, https://doi.org/10.1080/07315724.2012. 10720024.

This work is available in Open Access model and licensed under a Creative Commons Attribution-NonCommercial 3.0 Poland License - http://creativecommons.org/ licenses/by-nc/3.0/pl/deed.en. 